\title{
Mechanical properties of masonry repair dolomitic lime-based mortars
}

J. Lanas ${ }^{\text {a }}$, J.L. Pérez Bernal ${ }^{\text {b }}$, M.A. Bello ${ }^{\text {, }}$, J.I. Alvarez ${ }^{\mathrm{a}, *}$

a Departamento de Química, University of Navarra, 31080 Pamplona, Spain

b Departamento de Química Analítica, University of Sevilla, Apdo. 1065, 41012

Sevilla, Spain

$\mathbf{N}^{0}$ of pages: 38

$\mathbf{N}^{\mathrm{o}}$ of tables: 8

$\mathrm{N}^{\mathrm{o}}$ of figures: 8

Keywords: Dolomitic Lime. A: Curing. B: Particle Size Distribution. C: Carbonation, C: Compressive Strength.

Please, send all correspondence to:

Dr. José I. Alvarez Galindo

Dpto. de Química

Fac. de Ciencias

Universidad de Navarra

$\mathrm{C} /$ Irunlarrea s/n

31.080 Pamplona (Navarra)

Spain

Phone: 34948425600

Fax: 34948425649

E-mail: jalvarez@unav.es 


\title{
Mechanical properties of masonry repair dolomitic lime-based mortars
}

\author{
J. Lanas ${ }^{\text {a }}$, J.L. Pérez Bernal ${ }^{\mathrm{b}}$, M.A. Bello ${ }^{\mathrm{b}}$, J.I. Alvarez ${ }^{\mathrm{a}, *}$ \\ a Departamento de Química, University of Navarra, 31080 Pamplona, Spain \\ b Departamento de Química Analítica, University of Sevilla, Apdo. 1065, 41012 \\ Sevilla, Spain
}

ABSTRACT: 180 different mortars made with a dolomitic lime and different aggregates were prepared in order to be used in restoration works. This paper focuses on the effect of technological variables on pore structure and mechanical properties of dolomitic lime-based mortars. Compressive and flexural strengths of the specimens were discussed according to curing time, binder:aggregate ratios, attributes of the aggregates and porosity, at long-term tests.

A strong increase in the strength of mortars has been found after 365 curing days as compared to 28 curing days. The strength has been mainly attributed to the portlandite carbonation, because no significant changes have been observed in the brucite. However, higher strengths than similar aerial lime-based mortars led to think in other mechanism which increases the strength: the calcite formation through a reaction of dedolomitization (alkali carbonate reaction, ACR) and the brucite crystallization were discussed.

The pore structure has presented a significant influence on the strength. More binder amounts mean more strength due to the higher values of open porosity, which allows the carbonation process. The aggregate characteristics have been correlated with the strength and porosity. Limestone and angle-shaped aggregates, reducing large pores, cause a strength increment.

Keywords: Dolomitic Lime. A: Curing. B: Particle Size Distribution. C: Carbonation, C: Compressive Strength. 


\section{Mechanical properties of masonry repair dolomitic lime-based mortars}

\section{Introduction}

The use of materials similar to the original ones in a restoration process is an oft repeated recommendation of many institutions, such as ICOMOS or ICCROM [1, 2]. Some previous works have insisted upon the compatibility between the new repair mortar and the original components of the masonry [3-6]. The use of cement-based mortars in the restoration works, extensive damage to the ancient masonry has now been established [4-6]. Cement-based mortars have shown problems related to a high content of soluble salts, lower permeability and excessively high compressive strength [5]. In this sense, owing to the degree of movement in masonry structures, a repair mortar must be capable of accommodating movement. Repair mortar which is too strong restrains movement and leads to stress that can cause failure in the original masonry $[3,7]$.

Taking into account the increasing interest in the use of lime-based mortars for the restoration of historic structures, an earlier study by our group focused on the mechanical behavior of aerial lime-based mortars [8]. Aerial lime mortar is the most widely used in historical-artistic constructions, but some historical buildings also include dolomitic lime-based mortars [9-11]. Thus, there is a scientific interest in the study of the long-term mechanical behavior of dolomitic lime-based repair mortars in order to select a suitable mortar mixture for restoration works. Although both kind of mortars (aerial lime and dolomitic lime-based) are similar in some aspects, the occurrence of magnesium components establishes some differences related to composition and properties [12]. 
In general, lime-based mortars harden due to the carbonation process of portlandite transforming into calcite. In dolomitic lime-based mortars, brucite can also (theoretically) react with $\mathrm{CO}_{2}$ to form a magnesium carbonated compound. However, on the contrary of the portlandite, previous work has shown no evidence that $\operatorname{Mg}(\mathrm{OH})_{2}$ carbonates to $\mathrm{MgCO}_{3}$ [13-14]. The formation of the different magnesium carbonates depends on the special carbonation conditions, for example: in a $\mathrm{CO}_{2}(\mathrm{~g})$ excess $\mathrm{MgCO}_{3}$ could be obtained after formation of $\mathrm{Mg}\left(\mathrm{HCO}_{3}\right)_{2}$ [13]; hydromagnesite (HY) is only formed in strictly controlled conditions [12], for example, when the solution $\mathrm{pH}$ range between 7.5-9.0 and in $\mathrm{CO}_{2}(\mathrm{~g})$ excess conditions [14]. This reference states that the low solubility of the $\mathrm{Mg}(\mathrm{OH})_{2}$ restricts its reactivity; nesquehonite $\left(\mathrm{MgCO}_{3} \cdot 3 \mathrm{H}_{2} \mathrm{O}\right)$ could be obtained by control of the temperature and $\mathrm{pH}$ conditions [14].

From these facts the complexity of the $\mathrm{Mg}^{2+}-\mathrm{HCO}_{3}{ }^{-}-\mathrm{CO}_{3}{ }^{2-}-\mathrm{H}_{2} \mathrm{O}$ system may be inferred, and that it is strongly influenced by the conditions (temperature, $\mathrm{pH}, \mathrm{CO}_{2}$ flow, ...). In the present work, special conditions have not been applied to the specimens, the possible formation of these different magnesium carbonates or the brucite crystallization could affect to the mechanical behavior of the mortar [15].

On the other hand, in some cases, other aspects could be appreciable: the dedolomitization reaction of the dolomite (Eq. 1) [16-18].

$\mathrm{CaMg}\left(\mathrm{CO}_{3}\right)_{2}+\mathrm{Ca}(\mathrm{OH})_{2}=2 \mathrm{CaCO}_{3}+\mathrm{Mg}(\mathrm{OH})_{2}$ Eq. 1

In this process dolomite reacts with portlandite, producing calcite and brucite [16]. This reaction is in agreement with the well-known fact that the calcite-brucite pair is more stable than the dolomite-portlandite pair $[17,18]$. The binder used to prepare the specimens (slaked light calcined dolomite, LCD) has dolomite and portlandite in its 
composition. Following the mortar volumes of the solids involved the reaction results in an increase of volume of $1.13 \%$. Regarding this reaction, a previous study has established the dissolution rate of the dolomite as the limiting factor [16]. This dissolution proceeds very slowly at room temperature, because the heterogeneous nucleation of calcite on the dolomite surface creates a protective layer inhibiting the dissolution of dolomite. This alkali-carbonate reaction (ACR) has been described for cement-based mortars, and it has been identified as potentially expansive and responsible for a strength decrease in these kinds of mortars [16-18].

In the present work, it is necessary to consider the occurrence of this dedolomitization and its influence on the mechanical properties.

In view of the absence of the systematic studies in the literature, this paper focuses on the factors affecting the mechanical behavior in different repair dolomitic lime-based mortars. The prepared specimens have been studied in long-term tests and different factors have been discussed: curing time, binder:aggregate ratios, nature and particle size distributions of the aggregates, and porosity.

The final aim is to obtain knowledge about the mechanical behavior of these materials in order to prepare adequate dolomitic lime-based mortars for restoration works.

\section{Experimental work}

\subsection{Mortar preparation}

A dolomitic lime has been used to prepare the mortars. This dolomitic lime is a commercial lime of the class DL 85 according to European standards [19], supplied by Dolomitas del Norte. Fig. 1 shows its X-ray diffractogram.

From the results, it can be observed that this is a light calcined dolomite (LCD). In order to prepare the specimens, this LCD was slaked in an excess of water during 16 days 
until the amount of MgO was less than 10\%. The slaked LCD (light calcined dolomite) consisting mainly of portlandite $\left(\mathrm{Ca}(\mathrm{OH})_{2}\right)$ and brucite $\left(\mathrm{Mg}(\mathrm{OH})_{2}\right)$, and also some amounts of calcite $\left(\mathrm{CaCO}_{3}\right)$ and dolomite $\left(\mathrm{CaMg}\left(\mathrm{CaCO}_{3}\right)_{2}\right)$ (Table 1 and Fig. 2).

In this work, silico-calcareous and pure limestone aggregates were used. The characteristics and chemical composition [20], the mineralogical characterizations and particle size distributions are shown in Table 2, Table 3 and Fig. 3 respectively. CTH Navarra provided the aggregates, which have controlled granulometry.

The binder:aggregate ratios (B/Ag) prepared were (1:1), (1:2), (1:3), (1:4) and (1:5), by volume. Volume proportions of compounds were converted in weight to avoid measurement imprecision on mixing process (see Table 4).

The mortar pastes were obtained using the amount of water required to achieve normal consistency and a good workability (measured by the flow table test) (Table 5 presents these results together with the amount of water added) [21]. The mixer used was a Proeti ETI 26.0072 [22]. Aggregate and lime were blended for 5 min. Water was then added and mixed for 5 min at low speed, and finally for 1 min at high speed. The mortars were cast in prismatic 40x40x160 mm moulds [23] and demoulded $72 \mathrm{~h}$ later. The pastes were slightly compacted [22] to remove air bubbles and voids. Curing was carried out at ambient laboratory conditions until the test day (RH $60 \pm 10 \%$ and $20 \pm$ $\left.5^{\circ} \mathrm{C}\right)$.

A total of nine specimens of each $\mathrm{B} / \mathrm{Ag}$ ratio were prepared; hence, 180 specimens (45 of each aggregate) have been studied. Tests and analyses were performed, using the techniques described below, after curing times of 3, 7, 28, 91182 and 365 days. Two specimens were tested at 28, 91 and 182 days, but only one at 3, 7 and 365 days. The reported results were an average value of the similar specimens, and the coefficients of variation were below $6.5 \%$ in compressive strength results. 


\subsection{Analytical methodology}

\subsubsection{Mechanical properties}

The three-point flexural tests were carried out on the mortar specimens using a Frank/Controls 81565 compression machine at low rates of loading ( $4 \mathrm{~mm} / \mathrm{min}$ ). Flexural strength determination was done on the Ibertest IB 32-112V01.

Compression strength tests were conducted on the two fragments of each specimen resulting from the preceding flexural test. Compression strength determination was done on a Proeti ETI 26.0052. The rate of loading was $10 \mathrm{~mm} / \mathrm{min}$. The reported results are the average values.

\subsubsection{Mineralogical analysis}

A significant portion of each specimen was ground in an agate mortar. Samples were taken from the core and from the edges of the mortar specimens to avoid differences in the carbonation depth.

Mineralogical phases were determined by means of XRD using a Bruker D8 Advance diffractometer (Karlsruhe, Germany), according to the diffraction powder method, with a CuKa1 radiation and $0.02^{\circ} 2 \theta$ increment and $1 \mathrm{~s} \cdot \mathrm{step}^{-1}$, sweep from $10^{\circ}$ to $80^{\circ} 2 \theta$. The results were compared with the ICDD database.

\subsubsection{Thermal analysis}

Differential thermal and thermogravimetric analysis (DTA-TG) were carried out using a simultaneous TGA-sDTA 851 Mettler Toledo thermoanalyser (Schwerzenbach, Switzerland) using alumina crucibles, with perforated lids, at $20^{\circ} \mathrm{C} \mathrm{min}^{-1}$ heating rate, under static air atmosphere, from ambient temperature to $1200^{\circ} \mathrm{C}$. 


\subsubsection{Pore structure and microstructure}

The pore structure was evaluated after 365 days of curing (at which age a high level of carbonation is assumed). Two methods were used:

a) Open porosity measurement: the total porosity is expressed as $\mathrm{P}$, in percent, and is determined according to the water saturation test [24] with a hydrostatics balance.

b) Pore size distribution evaluated using a mercury intrusion porosimetry technique (Micromeritics 9320 Poresizer), which automatically registers pressure, pore diameter, intrusion volume and pore surface area.

Scanning electron microscopy (SEM) on a Digital Scanning Microscope DSM-940 A Zeiss was used for microscopic observations of the microstructure of the mortars.

\section{Results and discussion}

\subsection{Influence of curing time}

At early ages dolomitic lime-based mortars loses excess water and shrinkage occurs. At almost the same time, the carbonation process of portlandite transforming into calcite starts, and the mortar hardens.

Lime-based mortars can take many years to reach total carbonation [25]. A similar behaviour can be expected for dolomitic lime-based mortars. In this work the degree of mortar carbonation have been determined through XRD and TG. After 1 year of curing, a certain amount of brucite and portlandite remained uncarbonated in all the samples, as can be seen by the occurrence of the $\mathrm{Mg}(\mathrm{OH})_{2}$ and $\mathrm{Ca}(\mathrm{OH})_{2}$ diffraction peaks in XRD patterns and the weight loss at $\sim 400$ and $480^{\circ} \mathrm{C}$ in TG results, indicating, respectively, the dehydroxilation of both hydroxides (Tables 6 and 7 show the XRD semi- 
quantitative data and the TGA values for mortars with Ag-2 aggregate, respectively. Fig. 4 shows the TG data for (1:1) samples with Ag-2) [26].

It is true that owing to the binder hardening the mechanical strengths increase with curing time; however, it is unknown: (i) the age at which dolomitic lime-based mortars reach their maximum strength; (ii) the reactions and transformation of the brucite and what magnesium compounds are formed; (iii) the degree of the portlandite carbonation and the possible transformation of the brucite as a function of the curing time; (iv) the influence of all these factors on the strength.

As a general behaviour, independent of aggregate type and dosage, the compressive and flexural strength values have shown a large increment in strength between 28 days and 365 curing days. Fig. 5 shows the compressive and flexural strengths for different ratios, prepared with different aggregates, as a function of curing time.

According to the results, a greater strength increment can be observed for mortars with (1:1) B/Ag ratio. As an example, the specimen with Ag-4 (1:1) B/Ag has shown a compressive strength 4 times more at 365 days than at 28 days, and a flexural strength twice more after 365 days than after 28 days. In addition, the (1:1) B/Ag mortars have developed an outstanding increment in strength between 182 and 365 curing days. In any case, (with (1:1) B/Ag) it can be stated that dolomitic lime-based mortars need a long time to obtain their strength. A typical curing time of 28 days used in cementbased mortars is not enough. This behaviour is similar to the aerial lime-based mortars [8], because of the portlandite content of the specimens: in allowing for a full carbonation, a longer curing time improves the mortar strength.

Other factors could have some influence in this strength increment. The results of XRD show that the dolomite content at 28 days is a lot higher than at 365 days (Fig. 6 shows as an example the results of (1:1) B/Ag mortars with Ag-2: a decrease in the strong 
diffraction peak of the dolomite can be observed). The amounts of brucite at 28 and 365 days are similar (Table 7). The disappearance of the dolomite and the preservation of brucite without carbonation could be due to the following factors: (i) during 1 year of curing the brucite has not carbonated substantially; (ii) the $\mathrm{Mg}(\mathrm{OH})_{2}$ has carbonated but also, at the same time, it has been formed by the reaction of dedolomitization [16-18], so the amount of brucite remains almost constant.

The complexity of the $\mathrm{Mg}^{2+}-\mathrm{HCO}_{3}{ }^{-}-\mathrm{CO}_{3}{ }^{2-}-\mathrm{H}_{2} \mathrm{O}$ system has been previously highlighted. Actually, the carbonation of brucite is a very slow process and the new compounds formed could vary as a function of the conditions [14]. This appears to be the more probable reason for this stability of the brucite. Furthermore, it has not been checked whether there is any magnesium carbonate due to the $\mathrm{Mg}(\mathrm{OH})_{2}$ carbonation. Brucite crystallization could improve the mortar strength: this behaviour can be similar to the occurrence of crystalline portlandite in aerial lime-based mortars, involving a porosity decrease and a strength increment [27].

However, the disappearance of the dolomite originally present in the specimens is not yet explained. The dedolomitization reaction could justify this fact. The new brucite formed could compensate for the slight amount of carbonated brucite (giving dolomite, probably). Although in cement-based mortars the ACR process has been associated with some expansion and cracking processes, dolomitic lime-based mortars are more porous materials, so the expansive phenomena have less mechanical repercussions, as can be checked in section 3.4. The newly formed calcite through this dedolomitization reaction could also improve the mortar strength. The influence on mechanical behaviour can be proved regarding the higher strength at 365 curing days for dolomitic lime-based mortars than for aerial lime-based mortars, made with the same aggregates and 
proportions [8]. All these facts are clear in (1:1) B/Ag samples, because in other B/Ag ratios the chemical changes can not be tested due to the small binder amount.

For the other ratios (1:2, 1:3, 1:4, and 1:5 $\mathrm{B} / \mathrm{Ag}$ ratios) the strength does not undergo a great change between 182 and 365 days, even in some samples, from 91 days, the strength increment is very slight.

On the other hand, the strengths determined at early ages (between 3 and 28 curing days, even 91 days in some cases) are not conclusive (Fig. 5), because they are strongly influenced by the water content of the mixture. Most of the mortars are still losing water after 28 days curing, even 91 at days (Fig. 7 shows the weight losses of the mortars with different aggregates in relation to curing time). The mortars made with angle-shaped aggregates need more water for their mix than the mortars made with rounded aggregates [28] (Table 5). For this reason, the specimens with Ag-2, Ag-3 and Ag-4 show higher weight losses owing to these mixtures having more water for the mixing process. Also, at early ages (28 curing days) the degree of carbonation was negligible as the amount of $\mathrm{Ca}(\mathrm{OH})_{2}$, which shows only slight changes in the TG results (Table 7).

\subsection{Influence of binder:aggregate ratio}

The behaviour of these dolomitic lime-based mortars is similar to the aerial lime-based mortars as can be checked in a previous work [8]. In all specimens tested after one curing year, the mortars with more binder content show the highest compressive and flexural strengths (Fig. 5). This fact can be proved irrespective of the type of aggregate used. A binder decrease in the mortar has reduced its strength.

There are small differences in strength between the ratios, (1:2), (1:3), (1:4) and (1:5). Higher differences can be checked comparing these ratios with the (1:1) and the others B/Ag mixtures. 
In some previous references it appears the (1:3) $\mathrm{B} / \mathrm{Ag}$ ratio is the most suitable mixture for repair mortars due to: (i) its highest strength [4]; (ii) the cracking phenomena when binder proportions are greater than (1:3) [6]. From our results, it can be clearly stated that (1:1) B/Ag ratio mortars have shown the highest strengths. A problem related to high amounts of binder is the cracking due to the shrinkage: a length reduction ranging around $2.5 \%$ can be tested for (1:1) specimens, however neither macro- nor microscopic cracks have been observed.

Dolomitic lime-based mortars are more porous materials than cement-based mortars, so the expansive phenomena have less mechanical repercussions. This fact could give an explanation about the absence of the cracking: dolomitic lime-based mortars are very porous materials, so they can tolerate expansive phenomena (for example ACR) or compression and closing phenomena, avoiding the cracking.

Probably higher strength would be achieved at higher B/Ag ratio than (1:1). As reported in our previous work [8], in aerial lime-based mortars large binder amounts (2:1 B:Ag) shown a strength increase, but a strong strength reduction has been proved when the binder amount increases beyond this ratio. The lower amount in aggregate has produced internal and surface cracks because of binder increment. A similar behaviour could be expected for dolomitic lime-based mortars. However, further studies will be necessary to confirm this fact.

As considered later, an increment in the percentage of aggregate fraction allows a higher percentage of large pores, which contribute to a strength reduction. The mortars increase their open porosity when binder amount raises, but also the mechanical strength increases due to a large pores reduction.

In order to establish the mechanical requirements of the specimens to be used in restoration works, the European Standards [29] present the minimum strength for each 
class of mortar. At 365 days, (1:1) B/Ag mortars made with limestone aggregates (Ag-3 and Ag-4) are M5are (mortars with at least $5 \mathrm{~N} / \mathrm{mm}^{2}$ of the compressive strength). B/Ag specimens with low binder percentage exhibit low strengths (Fig. 5).

\subsection{Influence of the aggregate characteristics}

Several attributes of the aggregates have some influence on the mechanical behaviour of the specimens. Firstly, in agreement with previous works [30], the grain size distribution of the aggregates used affects the strength. An adequate grain size distribution (Fig. 3) has allowed the development of a high strength in the mortar. Ag-3 and Ag-4 aggregates have presented a grain size distribution without rock fragments (gravel $>2 \mathrm{~mm}$ ) [31]. Mortars made with these aggregates have shown the highest flexural and compressive strength values (Fig. 5). However, Ag-1 and Ag-2, which contain pebbles in their composition, have contributed less to the mortar strength than Ag-3 and Ag-4.

In addition, chemical composition is important: Ag-1 and Ag-2 are of silico-calcareous, while Ag-3 and Ag-4 are pure limestone aggregates (Tables 2 and 3). Therefore, the nature of the aggregate is a factor affecting the mortar strength: the use of silicocalcareous aggregates produced a strength reduction. Limestone aggregates have shown higher strengths. The similarity that exists between a calcitic binder matrix and a limestone aggregate structure could be related to this increase of strength. In this sense, during portlandite carbonation, the calcite of the aggregate provides nucleating sites for the crystal growth. This syntaxial growth process develops strength enhancing the binder-aggregate interface [25,32]. As is discussed later, the percentage of large diameter pores in specimens with limestone aggregate is lower than with silico- 
calcareous aggregate: this fact supports these considerations and justifies the higher strength for the limestone aggregates.

In connection with this idea, the shape of the aggregate grains also appears to have some influence. Ag-2 specimens have shown higher strengths than Ag-1specimens. Ag1 and Ag-2 have very similar nature and grain size distributions, so the differences in strength could not be attributed to these factors. However, the shape of the grains is different: Ag-1 is rounded whilst Ag-2 contains angular grains (Table 2). This reason can justify the strength values: Ag-2 produces a good packing owing to its angular shapes, so it show a lower percentage of large pores (section 3.4) and improves the strength. However, Ag-1 hinders the adherence of the matrix and a packed structure.

\subsection{Porosity influence}

The influence of the porosity on strength of cement-based materials has been widely discussed [3]. Also in lime-based mortars, porosity has a great importance when mechanical behaviour is considered [8]. Due to the similarity between aerial lime-based mortars and dolomitic lime-based mortars, a great influence of porosity on the mortar strength can be expected. In cement-based mortars, a porosity increment when binder amount decreases causes a strength reduction. From the results of the open porosity (Table 7), it can be concluded that, contrary to cement-mortars, in the specimens tested large binder amounts are related to a porosity increase. The slaked light calcined dolomite (LCD) contributes more to the porosity than the aggregate, whereas Ordinary Portland Cement (OPC) contributes less to the porosity than the aggregate.

As it is aforementioned in section 3.2, the mortars with (1:1) B/Ag ratios have shown the highest strengths. However, these specimens present the highest values of open porosity due to the large amounts of binder. These results could seem contradictory 
because, in general, the less porosity a specimen presents, the higher the strength values [33]. In dolomitic lime-based mortars a certain degree of porosity can be favourable owing to several reasons: (i) firstly, a porosity increment allows a faster and more complete carbonation [34,35]: the transformation of the hydroxides aforementioned, especially portlandite into calcite, leads to a strength increase; (ii) due to this porosity, dolomitic lime-based mortars are less compact than the cement one: for this reason the possible ACR process (dedolomitization) does not cause cracking phenomena into the structure.

Nevertheless, in agreement with aerial lime-based mortars [8], it could be assumed that a great increase of porosity ( $>50 \%$ ) should lead to a drastic strength reduction.

About the pore size distribution, Fig. 8 presents the results in mortars with different $\mathrm{B} / \mathrm{Ag}$ ratios for all the aggregates used, after 1 year of curing. It can be observed that the binder, slaked LCD, contributes to the small diameter pores (around $0.1 \mu \mathrm{m}$ diameter). This fact can be proved because, in all cases, regardless of the aggregate used, the specimens with the highest $\mathrm{B} / \mathrm{Ag}$ ratio have shown the highest values of porosity around $0.1 \mu \mathrm{m}$ of pore diameter, i.e. more binder amount means a greater peak in this pore size. In Fig. 8 the specimens with Ag-1 shows their main porosity values between 170-10 $\mu \mathrm{m}$ of pore diameter. Although these large pores also exist in the other specimens their percentage are lower. This fact indicates clearly that Ag-1 contributes to this pore diameter, probably owing to the rounded shape of this aggregate, which make difficult to obtain a good packing (section 3.3) [36]. These large pores cause a strength reduction, as can be checked in Fig 5.

The aggregates made up of crushed stones, with angular edges, silico-calcareous (Ag-2) and limestone (Ag-3 and Ag-4) contribute to pore diameters around 1 to $3 \mu \mathrm{m}$. In all 
these cases, an increase of the aggregate amount implies a higher amount of medium diameter pores.

It can be shown that an increase in the percentage of large pores $(170-10 \mu \mathrm{m})$ occurs when the amount of aggregate increases. These large pores have evident mechanical repercussions: the strength values decrease when the B/Ag ratio decreases (section 3.2). This statement can be reinforced by the evolution of medium sized pores (10-0.02 $\mu \mathrm{m})$ : in general, the percentage of medium sized pores increases when the aggregate amount rises.

The percentage of large pores is higher in the mortars with silico-calcareous aggregates than in the mortars with limestone aggregates: this fact shows an agreement with the lower strengths observed for specimens with siliceous aggregates, and it confirms that by providing nucleating sites for the crystal growth during portlandite carbonation, limestone aggregates improve the binder-aggregate interface reducing the large pores and increasing the strength.

\section{Conclusions}

1. The age at which dolomitic lime-based mortars reach their maximum strength is around 91 days for the studied silico-calcareous aggregates and B/Ag ratios (1:2) to (1:5). It is necessary 365 days (or even more) for calcareous aggregates and (1:1) $\mathrm{B} / \mathrm{Ag}$ ratio.

2. No significant changes have been observed in the brucite during the experiments. This fact can be due to the very slow carbonation process and/or a dedolomitization reaction (alkali-carbonate reaction, ACR) between $\mathrm{Ca}(\mathrm{OH})_{2}$ and dolomite present in the specimens. In any case, the newly formed calcite through ACR and the brucite crystallization improve the strength further than similar aerial lime-based mortars. 
3. Specimens with more binder content show the highest compressive and flexural strengths.

4. After one curing year, some amount of portlandite remains uncarbonated.

5. Mortars with the highest binder proportions have the highest values of open porosity: they make carbonation easier, which contributes to mortar strength improvements. In addition, the expansive phenomena related to a possible ACR do not cause cracks into the mortar due to the higher porosity.

6. A suitable grain size distribution of the aggregate has allowed developing high mortar strength.

7. Limestone aggregates exhibits the highest strength because they give a large diameter pores reduction. This pore reduction is because of the syntaxial growth of the calcite and of the angle-shaped grains.

\section{Acknowledgements}

The present study was supported by the Spanish Ministerio de Ciencia y Tecnología, Plan Nacional de Investigación, Desarrollo e Innovación Tecnológica (I+D+I) program, Project MAT 2000-1347.

The authors would like to thank José María Galech (CTH, Navarra) and R. Guzman (Dolomitas del Norte, Cantabria) for the material supplied. We are also grateful to Dr. Jordana for its help with SEM observations. 


\section{References}

[1] Venice Charter, International Charter for the conservation and restoration of monuments and sites, Venice, 1964 (web site: <http://www.icomos.org/docs/venice_charter.html>).

[2] Conclusions of the Symposium "Mortars, cements and grouts used in the conservation of historic buildings”, Rome, Mater. Struct., 23 (1990) p. 235.

[3] M.J. Mosquera, D. Benitez, S.H. Perry, Pore structure in mortars applied on restoration. Effect on properties relevant to decay of granite buildings, Cem. Concr. Res. 32 (2002) 1883-1888.

[4] A. Moropoulou, A.S. Cakmak, G. Biscontin, A. Bakolas, E. Zendri, Advanced Byzantine cement based composites resisting earthquake stresses: the crushed brick/lime mortars of Justinian’s Hagia Sophia, Constr Build Mater 16 (2002) 543552.

[5] C. Rodriguez-Navarro, E. Hansen, W.S. Ginell, Calcium hydroxide crystal evolution upon aging of lime putty, J Am Ceram Soc 81 (11) (1998) 3032-3034.

[6] O. Cazalla, C. Rodriguez-Navarro, E. Sebastian, G. Cultrone, Aging of lime putty: effects on traditional lime mortar carbonation, J Am Ceram Soc 83 (5) (2000) 1070-1076.

[7] A.W. Hendry, Masonry walls: materials and construction, Constr. Build. Mater. 15 (2001) 323-330

[8] J. Lanas, J.I. Alvarez, Masonry repair lime-based mortars: factors affecting the mechanical behavior, Cem. Concr. Res. 33 (2003) 1867-1876.

[9] S. Bruni, F. Cariati, P. Fermo, A. Pozzi, L. Toniolo, Characterization of ancient magnesian mortars coming from northem Italy, Termochim. Acta, 321 (1998) 161165. 
[10] S. Vecchio, A. Laginestra, A. Frezza, C. Ferragina, The use of thermoanalytical techniques in the characterization of ancient mortars, Termochim. Acta, 227 (1993) 245-2223.

[11] R.G. Newton, J.H. Sharp, An investigation of the chemical constituents of some renaissance plasters, Stud. Conserv. 32 (1987) 163-175.

[12] C. Montoya, J. Lanas, M. Arandigoyen, I. Navarro, P.J. Garcia Casado, J.I. Alvarez, Study of ancient dolomitic mortars of the church of Santa María de Zamarce in Navarra (Spain): comparison with simulated standards, Thermochim. Acta 398 (2003) 102-122.

[13] A.I. Fernández, J.M. Chimenos, M. Segarra, M.A. Fernández, F. Espiell, Kinetic study of carbonation of MgO slurries, Hydrometallurgy 53 (1999) 155-167.

[14] A. Botha, C.A. Strydom, Preparation of magnesium hydroxy carbonate from magnesium hydroxide, Hydrometallurgy 62 (2001) 175-183.

[15] R.M. Dheilly, A. Bouguerra, B. Beaudoin, J. Tudo, M. Queneudec, Hydromagnesite development in magnesian lime mortar, Mater. Sci. Eng. A 268 (1999) 127-131.

[16] S. Galí, C. Ayora, P. Alonso, E. Tauler, M. Labrador, Kinetics of dolomiteportlandite reaction. Application to Portland cement concrete, Cem. Concr. Res. 31 (2001) 933-939.

[17] E. García, P. Alfonso, M. Labrador, S. Galí, Dedolomitization in different alkaline media: Application to Portland cement paste, Cem. Concr. Res. 2348 (2003) 1-6.

[18] E. García, P. Alfonso, E. Tauler, S. Galí, Surface alteration of dolomite in dedolomitization reaction in alkaline media, Cem. Concr. Res. 2349 (2003) 1-8.

[19] EN 459-1, Building Lime. Part 1: Definition, specification and conformity criteria (2001). 
[20] EN 196-2, Methods of testing cement. Part 2: Chemical Analysis of cement (1994).

[21] EN 1015-3, Methods of test for mortar for masonry. Part 3: Determination od consistence of fresh mortar (by flow table) (1999).

[22] EN 196-1, Methods of testing cement. Part 1: Determination of strength (1995).

[23] EN 1015-11, Methods of test for mortar masonry. Part 11: Determination of flexural and compressive strength of hardened mortar (1999).

[24] RILEM, 1980. Recommended tests to measure the deterioration of stone and asses the effectiveness of treatment methods, Mater Struct 13 (1980) 175-253.

[25] O. Cazalla, Morteros de cal. Aplicación en el patrimonio histórico, Unpublished PhD thesis (in Spanish), Universidad de Granada, Granada, 2002.

[26] T.L. Webb, in: R.C. McKenzie (Ed.), Differential Thermal Analysis, Academic Press, London, 1970, pp. 238-266.

[27] A. Moropoulou, G. Biscontin, A. Bakolas, K. Bisbikou, Technology and behavior of rubble masonry mortars, Constr. Build. Mater. 11 (2) (1997) 119-129.

[28] P. Gimenez Montoya, A. Garcia Messeguer, P. Moran Cabre, Hormigon armado, Ed. Gustavo Gili, S.A., Barcelona, 1979.

[29] EN 998-2, Specification for mortar masonry. Part. 2: Masonry mortar (2001).

[30] G. Baronio, L. Binda, N. Lombardi, The role of brick pebbles and dust in conglomerates based on hydrated lime and crushed bricks, Constr Build Mater 11 (1997) 33-40.

[31] USDA. United State Department of Agriculture. Natural Resources Conservation Service. Soil Survey Laboratory Methods Manual, Natl. Soil Surv. Cent. SSIR 42 (1996) p. 693.

[32] M. Heikal, M.H. El-Didamony, M.S. Morsy, Limestone-filled pozzolanic cement, Cem Concr Res 30 (2000) 1827-1834. 
[33] S.P. Pandey, R.L. Sharma, The influence of mineral additives on the strength and porosity of OPC mortar, Cem. Concr. Res. 30 (2000) 19-23.

[34] P. Mira, V.G. Papadakis, S. Tsimas, Effect of lime putty addition on structural and durability properties of concrete, Cem Concr Res 32 (2002) 683-689.

[35] D.R. Moorehead, Cementation by the carbonation of Hydrated Lime, Cem Concr Res 16 (1986) 700-708.

[36] Guía práctica de la cal y el estuco, Editorial de los Oficios, León, 1998, pp. 31. 
Table 1. Chemical analysis of the main components of the slaked $\mathrm{LCD}^{\mathrm{a}, \mathrm{b}}$.

\begin{tabular}{|c|c|c|c|c|c|c|c|c|}
\hline Lime & LOI (\%) & $\mathrm{SiO}_{2}(\%)$ & $\mathrm{CaO}(\%)$ & MgO (\%) & $\mathbf{R}_{2} \mathbf{O}_{3}{ }^{\mathrm{c}}(\%)$ & $\mathrm{SO}_{3}(\%)$ & $\mathrm{Na}_{2} \mathrm{O}(\%)$ & $\mathrm{K}_{2} \mathrm{O}(\%)$ \\
\hline $\begin{array}{c}\text { Slaked LCD } \\
\text { (Dolomitic } \\
\text { lime) }\end{array}$ & 31.05 & 0.00 & 41.00 & 27.10 & 0.97 & 0.26 & 0.08 & 0.04 \\
\hline
\end{tabular}

Table 2. Chemical analysis of the main components of the aggregates ${ }^{\mathrm{a}}$.

\begin{tabular}{|c|c|c|c|c|c|c|c|c|c|c|}
\hline Aggregate & $\begin{array}{l}\text { I. L. } \\
\text { (\%) }\end{array}$ & $\begin{array}{l}\mathrm{SiO}_{2} \\
(\%)\end{array}$ & $\begin{array}{c}\mathrm{CaO} \\
(\%)\end{array}$ & $\begin{array}{c}\text { MgO } \\
(\%)\end{array}$ & $\begin{array}{c}\mathrm{R}_{2} \mathrm{O}_{3}{ }^{\mathrm{C}} \\
(\%)\end{array}$ & $\begin{array}{l}\mathrm{SO}_{3} \\
(\%) \\
\end{array}$ & $\begin{array}{c}\mathrm{Na}_{2} \mathrm{O} \\
(\%)\end{array}$ & $\begin{array}{c}K_{2} \mathbf{O} \\
(\%)\end{array}$ & Origin & Shape \\
\hline Ag-1 & 15.06 & 57.69 & 19.00 & 1.53 & 5.69 & 0.08 & 0.36 & 0.48 & Pebbles & $\begin{array}{c}\text { Rounded } \\
\text { edges }\end{array}$ \\
\hline Ag-2 & 9.35 & 72.29 & 9.84 & 1.50 & 6.00 & 0.10 & 0.37 & 0.50 & $\begin{array}{c}\text { Crushed } \\
\text { stones }\end{array}$ & $\begin{array}{c}\text { Angular } \\
\text { edges }\end{array}$ \\
\hline Ag-3 & 43.10 & 0.49 & 52.83 & 2.28 & 1.14 & 0.57 & 0.07 & 0.05 & $\begin{array}{c}\text { Crushed } \\
\text { stones }\end{array}$ & $\begin{array}{c}\text { Angular } \\
\text { edges }\end{array}$ \\
\hline Ag-4 & 43.14 & 0.12 & 52.11 & 3.05 & 1.10 & 0.34 & 0.06 & 0.04 & $\begin{array}{l}\text { Crushed } \\
\text { stones }\end{array}$ & $\begin{array}{l}\text { Angular } \\
\text { edges }\end{array}$ \\
\hline
\end{tabular}

a Percentages related to original dry aggregate.

b The methods specified by the European Standard EN-196 were followed for the chemical analyses.

${ }^{\mathrm{c}} \mathrm{R}_{2} \mathrm{O}_{3}$ expresses the percentage of $\mathrm{Fe}, \mathrm{Al}$ and $\mathrm{Ti}$ as oxides.

Table 3. Results of X-ray diffraction in aggregates.

\begin{tabular}{lcc}
\hline Aggregate & $\begin{array}{c}\text { Calcite } \\
\left(\mathbf{C a C O}_{3}\right) \\
\text { ICDD 05-0586 }\end{array}$ & $\begin{array}{c}\alpha-Q u a r t z \\
\left(\mathbf{S i O}_{2}\right) \\
\text { ICDD 85-798 }\end{array}$ \\
\hline Ag-1 & $*^{\mathrm{a}}$ & $* * \mathrm{~b}$ \\
Ag-2 & $*$ & $* *$ \\
Ag-3 & $* * *^{\mathrm{c}}$ & $\mathrm{T}^{\mathrm{d}}$ \\
Ag-4 & $* * *$ & $\mathrm{~T}$ \\
\hline${ }^{\mathrm{a}} 10-50 \%$ & & \\
${ }^{\mathrm{b}} 50-90 \%$ & & \\
${ }^{\mathrm{c}}>90 \%$ & \\
${ }^{\mathrm{d}}$ Traces $(<5 \%)$ & & \\
\end{tabular}

Table 4. Equivalences volume proportion/weight proportion

\begin{tabular}{clccc}
\hline $\begin{array}{c}\text { Volume } \\
\text { Proportion }\end{array}$ & Material & $\begin{array}{c}\text { Volume } \\
(\mathbf{L})\end{array}$ & $\begin{array}{c}\text { Weight } \\
\text { (g) }\end{array}$ & $\begin{array}{c}\text { Weight } \\
\text { Proportion }\end{array}$ \\
\hline \multirow{2}{*}{$1: 1$} & Lime & 2.00 & 1400 & \\
& Aggregate & 2.00 & 3000 & $1: 2.14$ \\
\hline \multirow{2}{*}{$1: 2$} & Lime & 1.33 & 933.33 & \multirow{2}{*}{$1: 4.29$} \\
& Aggregate & 2.67 & 4000 & \\
\hline \multirow{2}{*}{$1: 3$} & Lime & 1.00 & 700 & $1: 6.43$ \\
& Aggregate & 3.00 & 4500 & \\
\multirow{2}{*}{$1: 4$} & Lime & 0.80 & 560 & \multirow{2}{*}{$1: 8.57$} \\
& Aggregate & 3.20 & 4800 & \\
\hline \multirow{2}{*}{$1: 5$} & Lime & 0.67 & 466.67 & \multirow{2}{*}{$1: 10.71$} \\
\hline & Aggregate & 3.33 & 5000 & \\
\hline
\end{tabular}


Table 5. Water added to the mixtures (mL) and flow table test results (mm).

\begin{tabular}{|c|c|c|c|c|c|c|}
\hline & & \multicolumn{4}{|c|}{ Aggregate } & \\
\hline & & Ag-1 & Ag-2 & Ag-3 & Ag-4 & \\
\hline \multirow{10}{*}{ 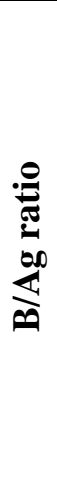 } & \multirow{2}{*}{ 1:1 } & 755 & 950 & 825 & 778 & $\mathrm{H}_{2} \mathrm{O}(\mathrm{mL})$ \\
\hline & & 133 & 135 & 143 & 138 & Flow test $(\mathrm{mm})$ \\
\hline & \multirow{2}{*}{ 1:2 } & 750 & 850 & 915 & 775 & $\mathrm{H}_{2} \mathrm{O}(\mathrm{mL})$ \\
\hline & & 142 & 130 & 155 & 143 & Flow test $(\mathrm{mm})$ \\
\hline & \multirow{2}{*}{$1: 3$} & 700 & 810 & 800 & 775 & $\mathrm{H}_{2} \mathrm{O}(\mathrm{mL})$ \\
\hline & & 133 & 126 & 138 & 142 & Flow test $(\mathrm{mm})$ \\
\hline & \multirow{2}{*}{$1: 4$} & 655 & 775 & 750 & 772 & $\mathrm{H}_{2} \mathrm{O}(\mathrm{mL})$ \\
\hline & & 122 & 119 & 148 & 143 & Flow test $(\mathrm{mm})$ \\
\hline & \multirow{2}{*}{$1: 5$} & 650 & 810 & 790 & 670 & $\mathrm{H}_{2} \mathrm{O}(\mathrm{mL})$ \\
\hline & & 117 & 134 & 146 & 148 & Flow test $(\mathrm{mm})$ \\
\hline
\end{tabular}

Table 6. XRD semi-quantitative results for dolomitic lime mortars with Ag-2.

\begin{tabular}{|c|c|c|c|c|c|c|}
\hline $\begin{array}{l}\text { B/Ag } \\
\text { ratio }\end{array}$ & $\begin{array}{c}\text { Dolomite } \\
\left(\mathrm{CaMg}\left(\mathrm{CaCO}_{3}\right)_{2}\right) \\
\mathrm{ICDD} \mathrm{36-0426} \\
\end{array}$ & $\begin{array}{c}\text { Calcite } \\
\left(\mathrm{CaCO}_{3}\right) \\
\text { ICDD 05-0586 } \\
\end{array}$ & $\begin{array}{c}\alpha-Q u a r t z \\
\left(\mathrm{SiO}_{2}\right) \\
\text { ICDD 85-798 }^{\mathrm{c}}\end{array}$ & $\begin{array}{c}\text { Portlandite } \\
\left(\mathrm{Ca}(\mathrm{OH})_{2}\right) \\
\text { ICDD 44-1481 } \\
\end{array}$ & $\begin{array}{c}\text { Brucite } \\
\left(\mathrm{Mg}(\mathrm{OH})_{2}\right) \\
\text { ICDD 44-1482 } \\
\end{array}$ & Day \\
\hline \multirow{6}{*}{$\ddot{ت}$} & $*$ a & $\mathrm{s}$ & $* *$ & * & $\mathrm{s}$ & 3 \\
\hline & $*$ & $*$ & $*$ & $*$ & $\mathrm{~s}$ & 7 \\
\hline & $*$ & $*$ & $*$ & * & $\mathrm{s}$ & 28 \\
\hline & $s^{b}$ & $* * \mathrm{~d}$ & $*$ & $\mathrm{~s}$ & $\mathrm{~s}$ & 91 \\
\hline & $t^{c}$ & $* * * \mathrm{e}$ & $*$ & $\mathrm{t}$ & $\mathrm{s}$ & 182 \\
\hline & $\mathrm{t}$ & $* * *$ & $*$ & $\mathrm{t}$ & $\mathrm{s}$ & 365 \\
\hline $\begin{array}{l}\text { a } 10-25 \\
\text { b } \\
\text { small } \\
\text { c } \text { traces } \\
\text { d } 25-50 \\
\text { e } 50-75\end{array}$ & $\begin{array}{l}\% \\
\text { amount }(5-10 \%) \\
(<5 \%) \\
\%\end{array}$ & & & & & \\
\hline
\end{tabular}


Table 7. TGA for dolomitic lime mortars with Ag-2.

\begin{tabular}{|c|c|c|c|c|}
\hline $\begin{array}{l}\mathrm{B} / \mathrm{Ag} \\
\text { ratio }\end{array}$ & $\begin{array}{c}\mathrm{Mg}(\mathrm{OH})_{2} \\
(\%)^{\mathrm{a}}\end{array}$ & $\begin{array}{c}\mathrm{Ca}(\mathrm{OH})_{2} \\
(\%)^{\mathbf{b}}\end{array}$ & $\begin{array}{l}\mathrm{CO}_{2} \\
(\%)^{\mathrm{C}}\end{array}$ & Day \\
\hline \multirow{6}{*}{$\ddot{\sim}$} & 9.63 & 10.68 & 12.55 & 3 \\
\hline & 8.60 & 10.65 & 11.75 & 7 \\
\hline & 8.96 & 11.31 & 12.58 & 28 \\
\hline & 9.21 & 9.81 & 12.23 & 91 \\
\hline & 9.50 & 8.49 & 12.40 & 182 \\
\hline & 8.17 & 5.52 & 15.13 & 365 \\
\hline \multirow{6}{*}{$\stackrel{\sim}{\ddot{H}}$} & 5.24 & 5.75 & 9.35 & 3 \\
\hline & 5.29 & 6.36 & 10.84 & 7 \\
\hline & 5.40 & 6.39 & 11.05 & 28 \\
\hline & 5.26 & 4.90 & 13.30 & 91 \\
\hline & 5.11 & 4.80 & 12.66 & 182 \\
\hline & 5.16 & 4.47 & 12.82 & 365 \\
\hline \multirow{6}{*}{$\stackrel{\mathscr{P}}{\ddot{\theta}}$} & 3.85 & 4.04 & 11.47 & 3 \\
\hline & 3.55 & 4.16 & 11.59 & 7 \\
\hline & 4.09 & 4.72 & 11.11 & 28 \\
\hline & 3.73 & 3.71 & 12.30 & 91 \\
\hline & 3.25 & 3.34 & 11.12 & 182 \\
\hline & 3.76 & 3.19 & 11.31 & 365 \\
\hline \multirow{6}{*}{$\stackrel{\sharp}{ت}$} & 2.92 & 2.68 & 13.28 & 3 \\
\hline & 2.95 & 3.56 & 10.07 & 7 \\
\hline & 3.12 & 3.15 & 13.46 & 28 \\
\hline & 3.12 & 2.90 & 11.34 & 91 \\
\hline & 2.87 & 2.64 & 12.07 & 182 \\
\hline & 3.05 & 2.68 & 9.98 & 365 \\
\hline \multirow{6}{*}{ بُ } & 2.21 & 1.71 & 12.69 & 3 \\
\hline & 2.32 & 2.70 & 10.84 & 7 \\
\hline & 2.55 & 2.45 & 13.81 & 28 \\
\hline & 2.50 & 2.49 & 11.05 & 91 \\
\hline & 2.22 & 2.00 & 13.77 & 182 \\
\hline & 2.32 & 2.12 & 12.95 & 365 \\
\hline
\end{tabular}

${ }^{\text {a }}$ Calculated from weight loss at $\sim 400^{\circ} \mathrm{C}$

${ }^{\mathrm{b}}$ Calculated from weight loss at $\sim 480^{\circ} \mathrm{C}$

${ }^{\text {c }}$ Calculated from weight loss between $600-900^{\circ} \mathrm{C}$

Table 8. Open porosity (\%) in mortars tested after 365 days.

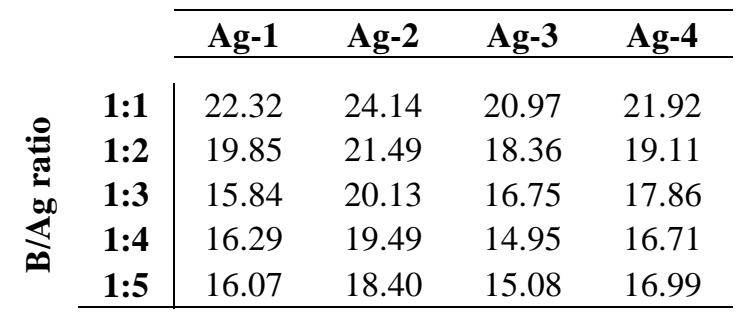




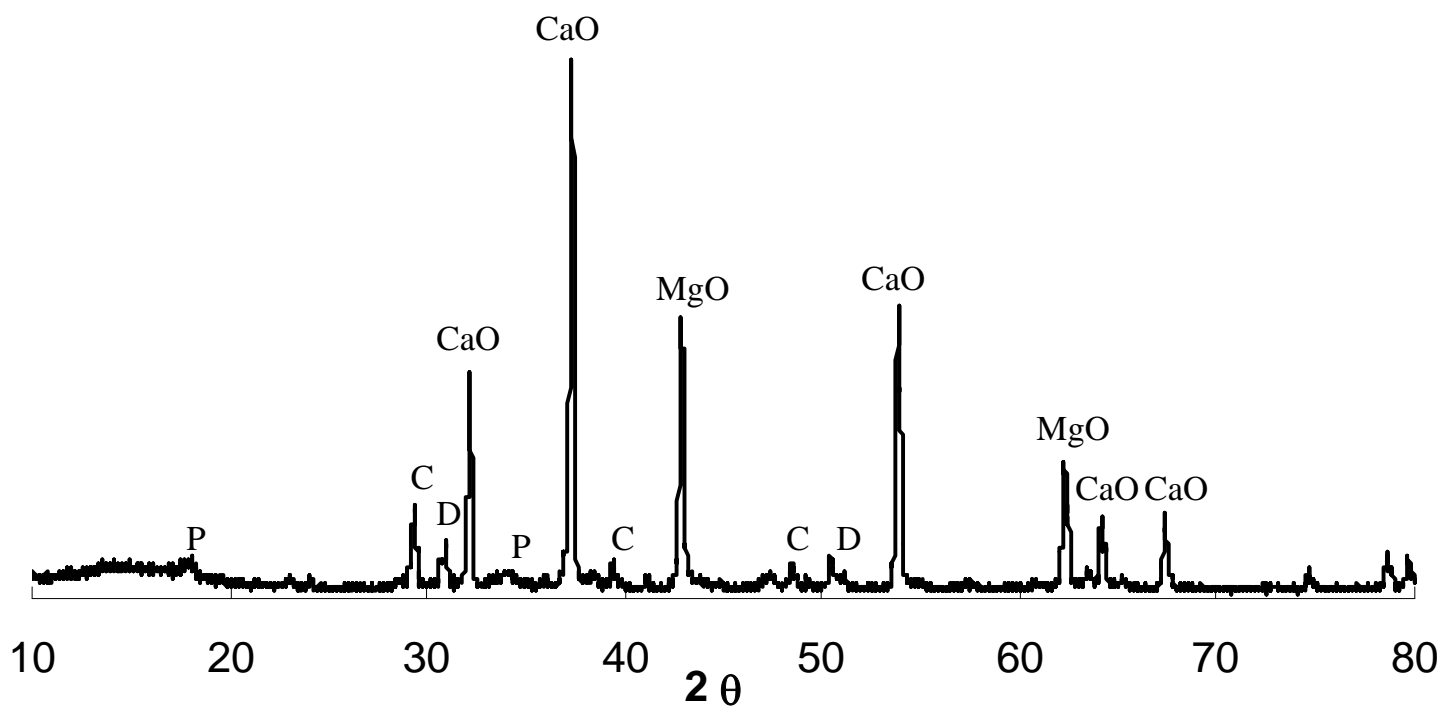

Figure 1 XRD of the LCD. P: Portlandite (ICDD 44-1481); C: Calcite (ICDD 05-0586); D: Dolomite (ICDD 36-0426); CaO: Calcium oxide (ICDD 37-1497); MgO: Magnesium oxide (ICDD 45-0946).

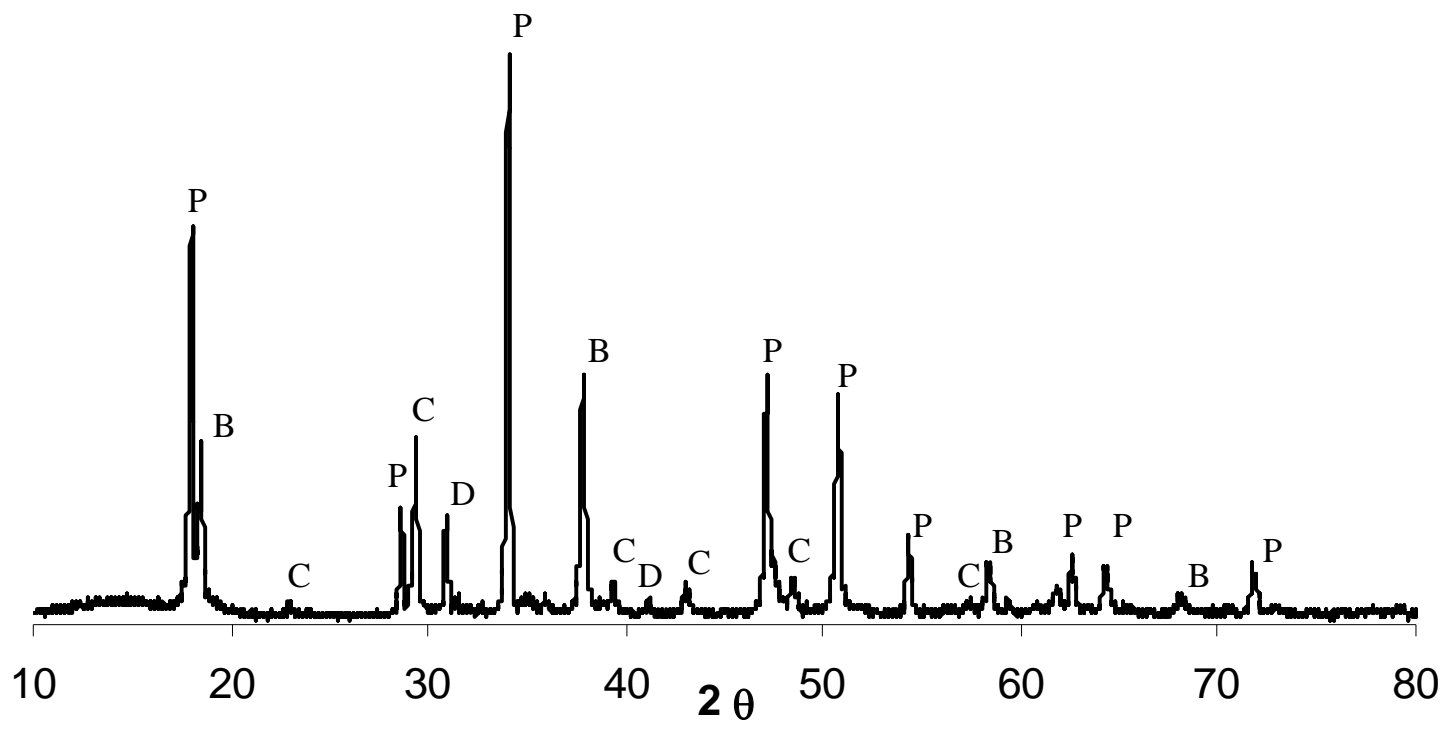

Figure 2. XRD of the slaked LCD. P: Portlandite (ICDD 44-1481); B: Brucite (ICDD 44-1482); C: Calcite (ICDD 05-0586); D: Dolomite (36-0426). 


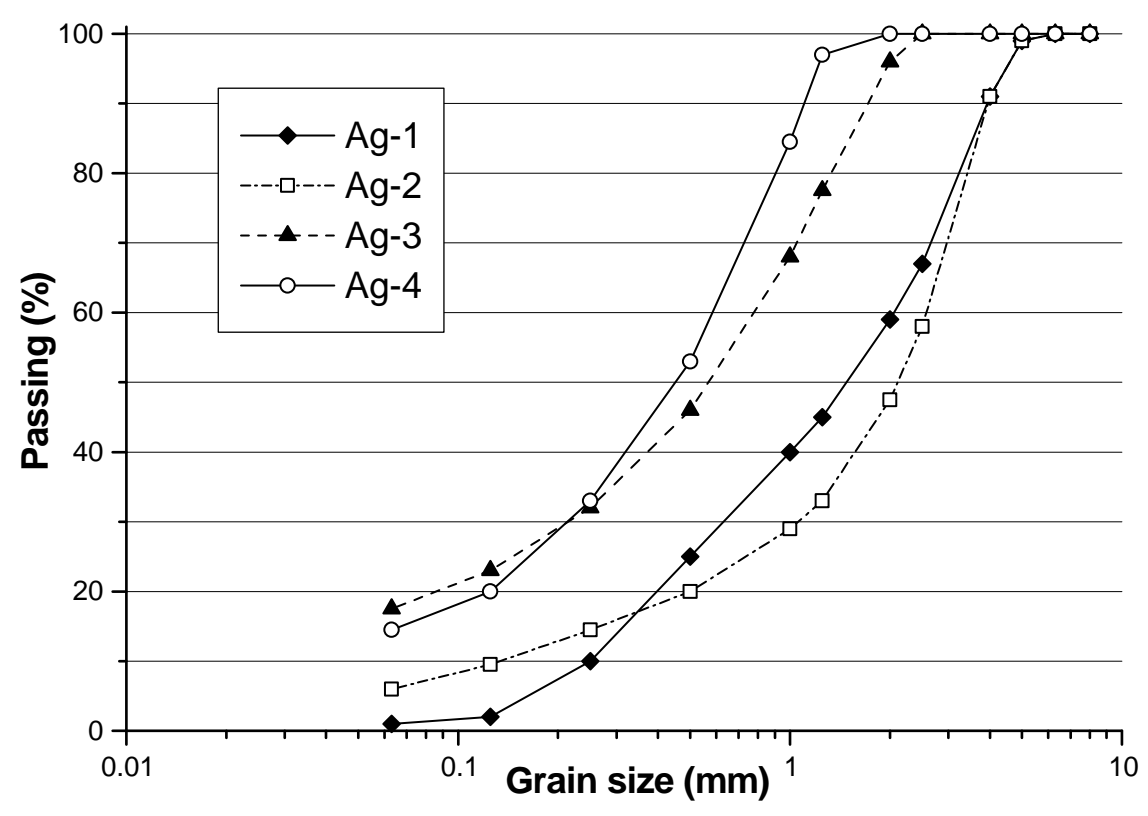

Figure 3. Grain size distributions of the aggregates.

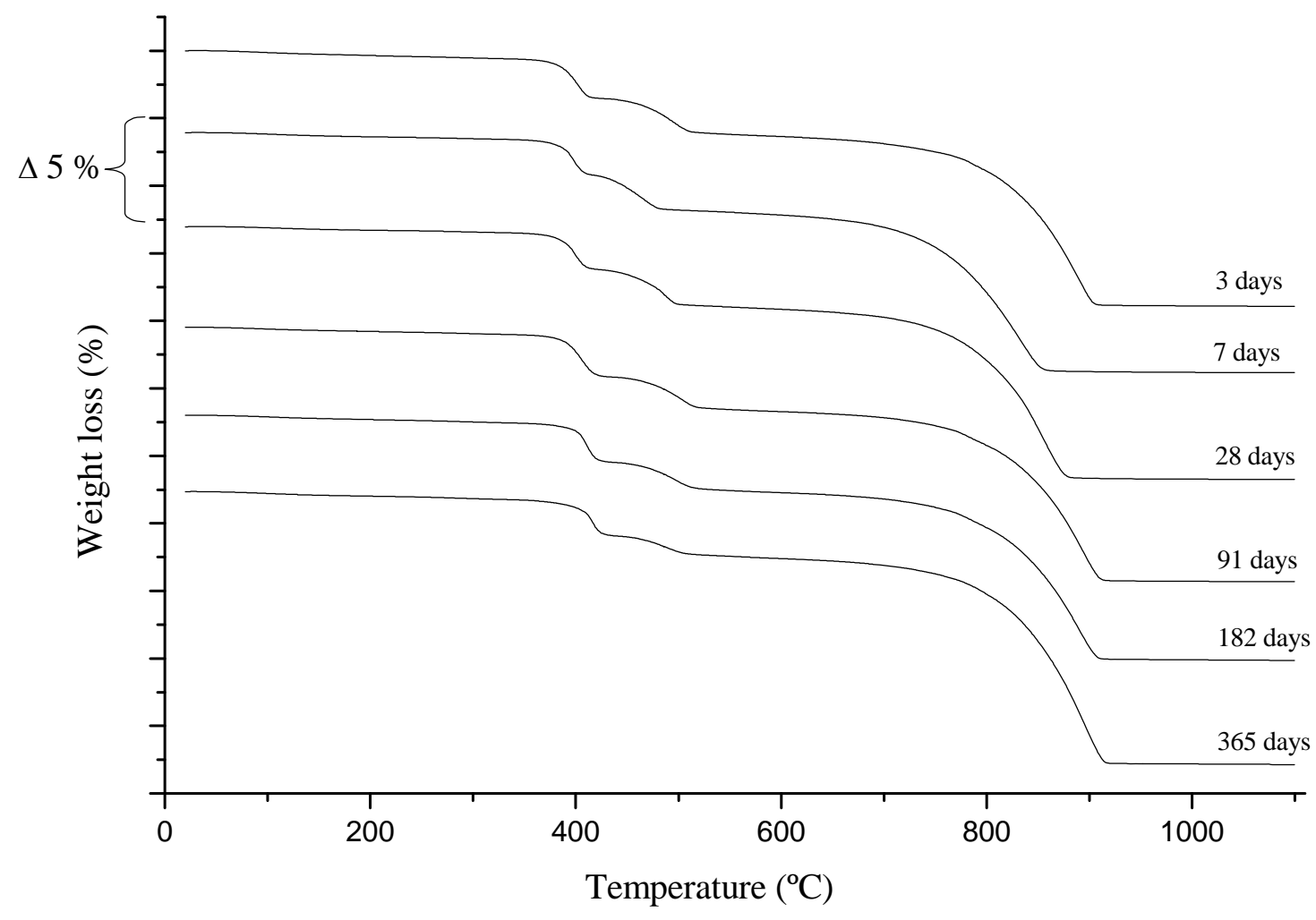

Figure 4. TG curves for (1:1) dolomitic lime mortars with Ag-2 at different curing times. 


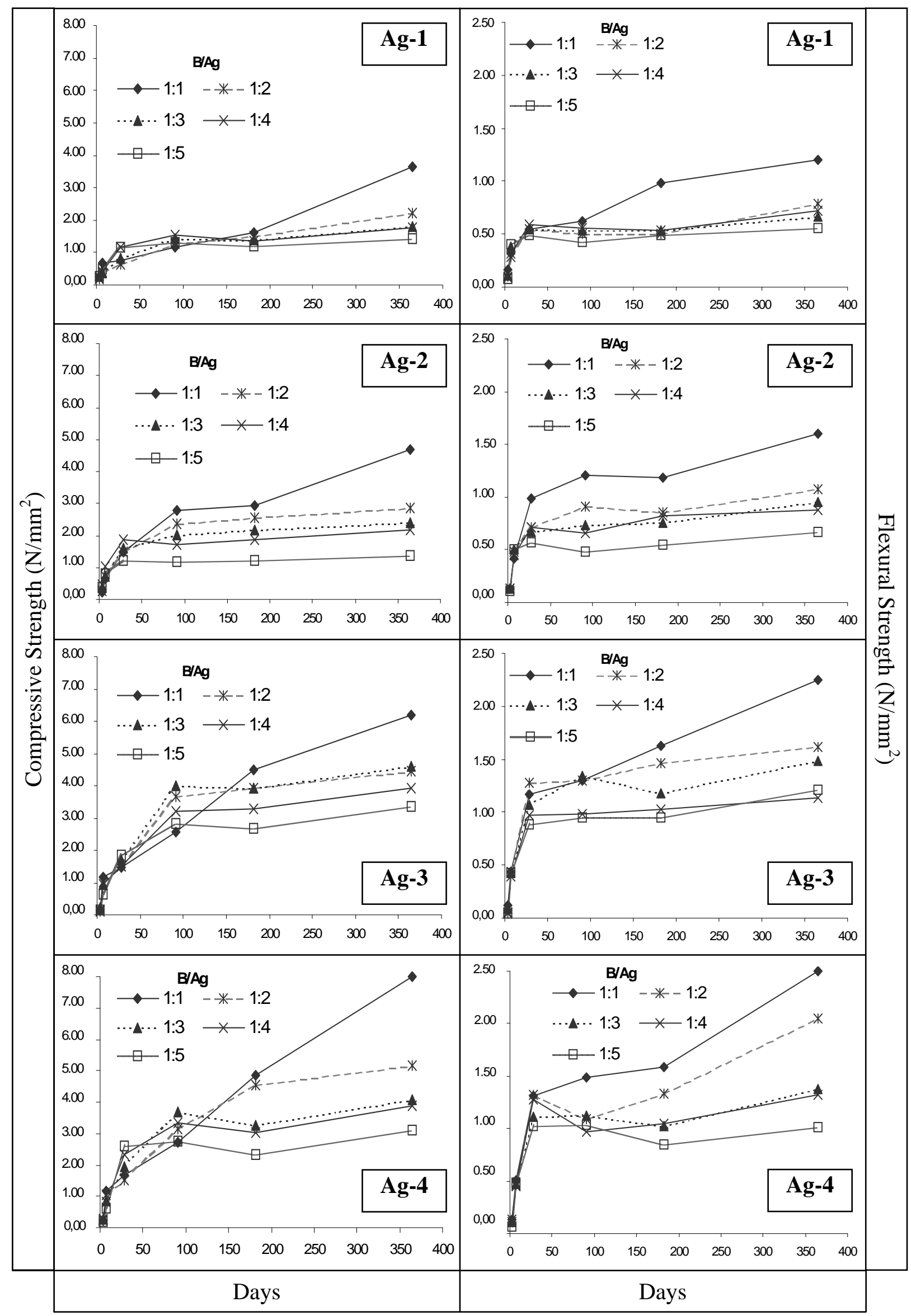

Figure 5. Strength results in dolomitic lime mortars with different aggregates vs. curing time. 


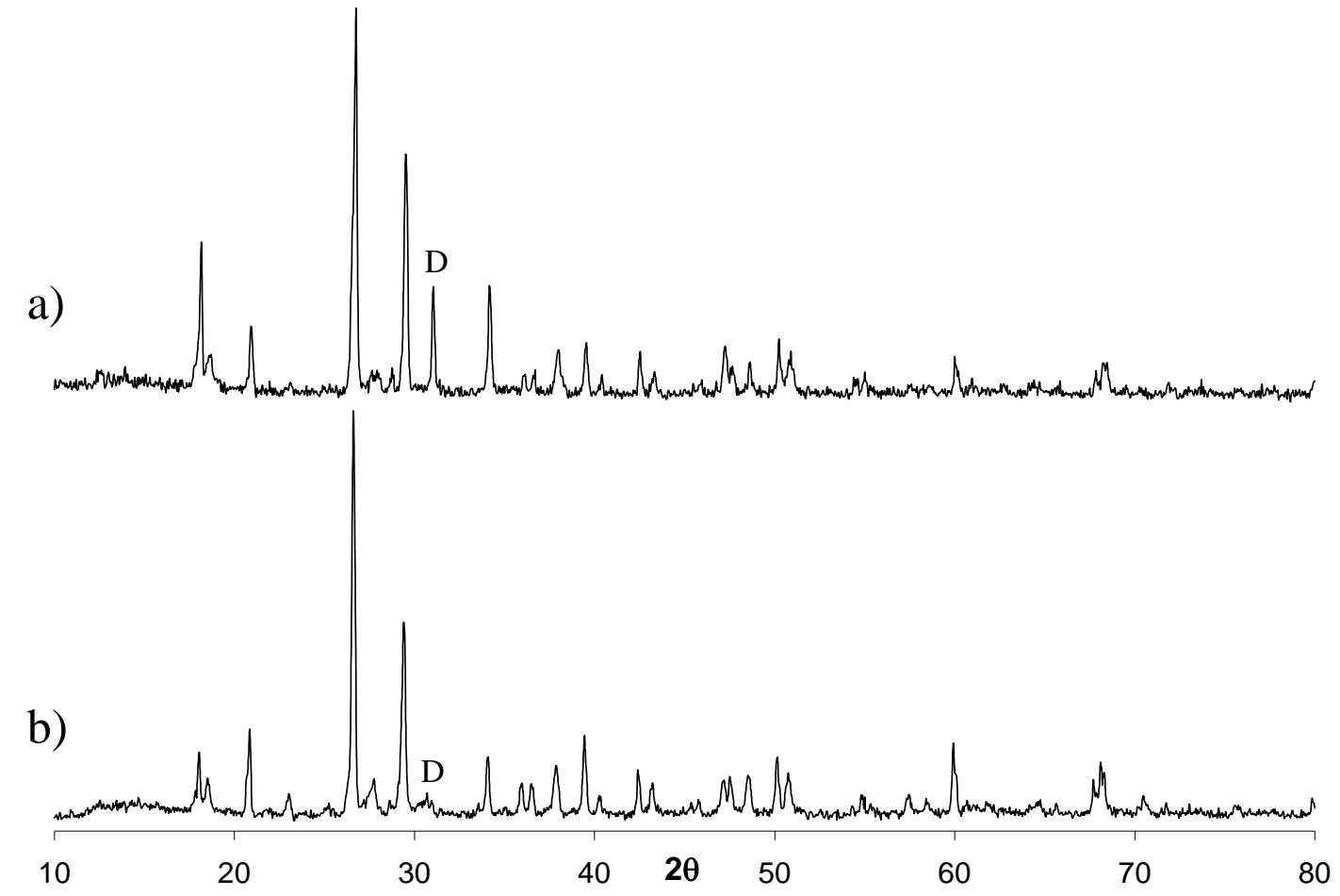

Figure 6. XRD for (1:1) B/Ag mortars with Ag-2. a) 28 curing days; b) 365 curing days. D: Dolomite (ICDD 36-0426).

Figure 7. Weight losses vs. curing time in dolomitic lime mortars with different aggregates.

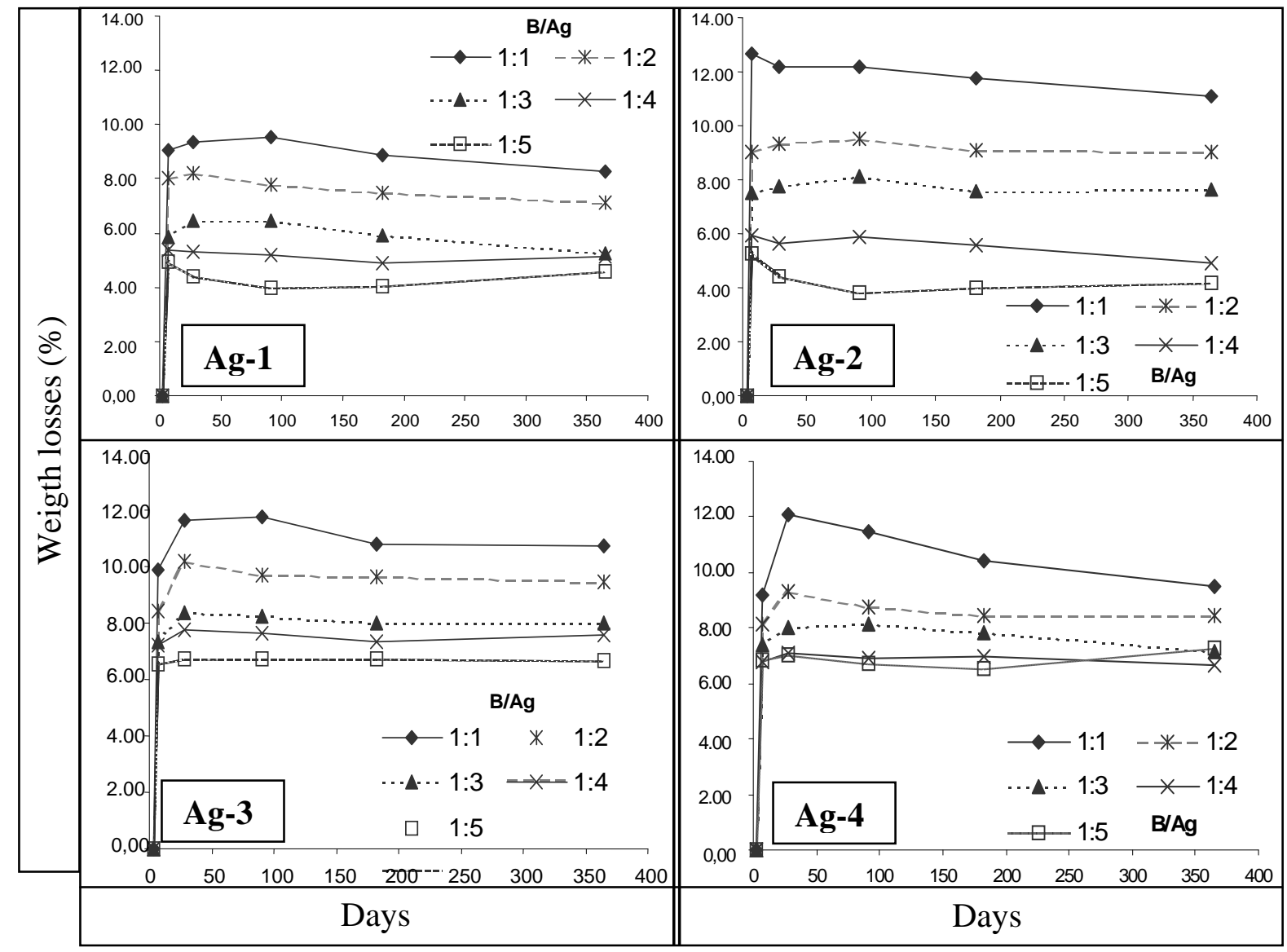



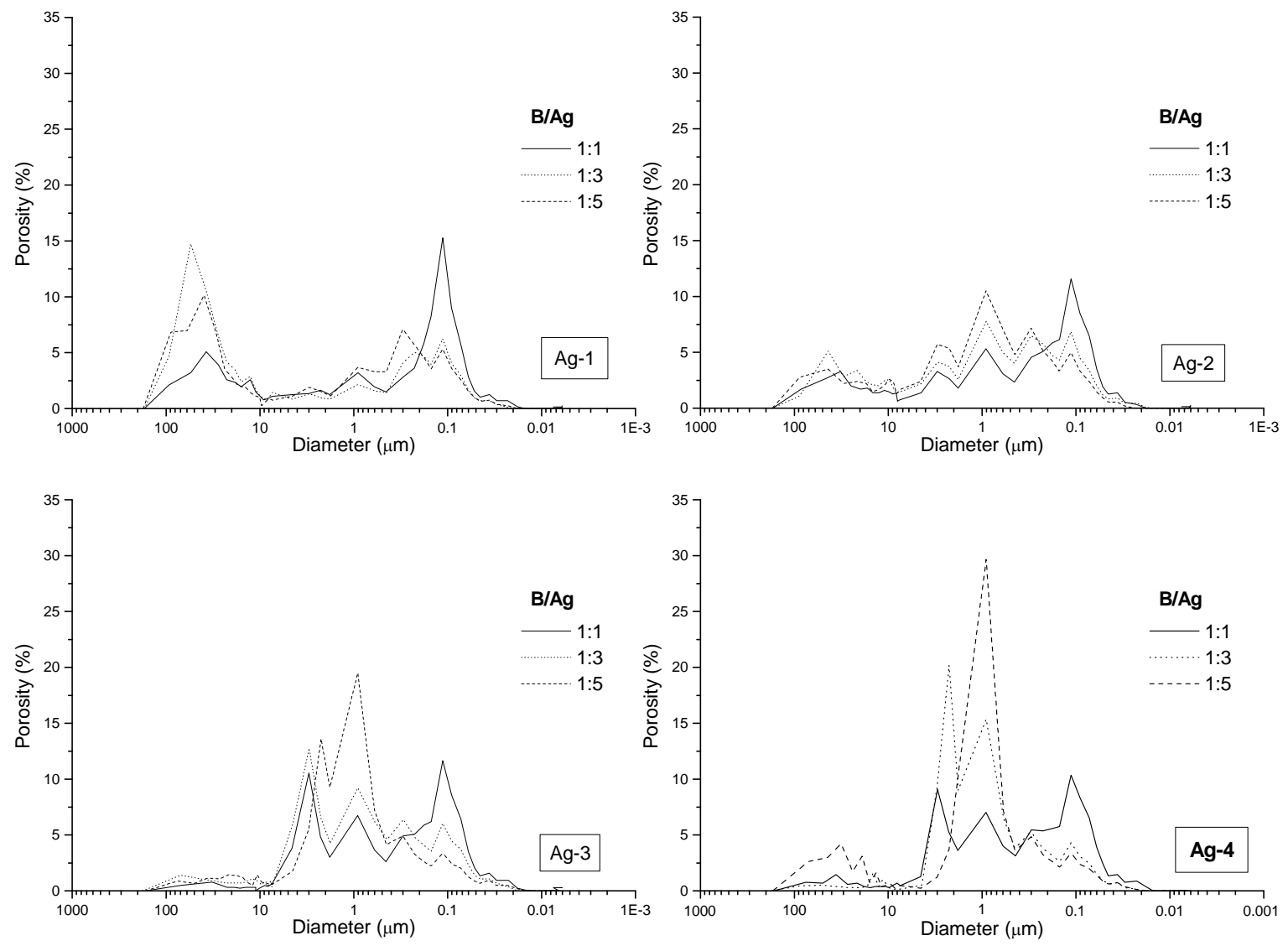

Figure 8. Results from mercury intrusion: Pore size distribution for dolomitic lime-based mortars with different aggregates at 365 days. 